\title{
Chemical Liaison Between Diabetes and Hypertension, Depression and Socio-economic Deprivation Impact in Both
}

\author{
ROXANA FURAU1\#, AMORIN REMUS POPA ${ }^{2 \#, ~ B O G D A N ~ S O C E A ~} 3$ 3,5\#, MIHAI DIMITRIU3,5\#, CRIS PRECUP1,6\#, \\ GHEORGHE OTTO FURAU ${ }^{1,6}$, MIRCEA ONEL ${ }^{1,6 *}$, RADU ROMOSAN ${ }^{4 *}$, DIANA CLAUDIA GHEORGHIU ${ }^{3 \#,}$ \\ NICOLAE GHEORGHIU5,7\#, CRISTIAN FURAU1,6\# \\ ${ }^{1}$ Vasile Goldis Western University of Arad, Faculty of Medicine, 86 L. Rebreanu Str., 310414, Arad, Romania \\ 2University of Oradea, 1 University Str.,410087, Oradea, Romania \\ 3Sf. Pantelimon Emergency Clinical Hospital, 340-342 Soseaua Pantelimon, 021659, Bucharest, Romania \\ ${ }^{4}$ Victor Babes University of Medicine and Pharmacy, 2 Eftimie Murgu Sq., 30077, Timisoara, Romania \\ ${ }^{5}$ Carol Davila University of Medicine and Pharmacy, 37 Dionisie Lupu, 020021, Bucharest, Romania \\ ${ }^{6}$ Emergency Clinical County Hospital of Arad, 2-4 Andreny Karoly Str., 310037, Arad, Romania \\ 'Elias Emergency Hospital 17 Marasti Str., 011461, Bucharest, Romania
}

\begin{abstract}
Approaching two prevalent chronic conditions as Diabetes mellitus (DM) and High blood pressure/ Hypertension (HTN) from a socio-economic and mental health perspectives using Beck Depresion Inventory (BDI) and EPICES score simultaneouslyis a first for Arad County and for Romania. This research demonstrates the connection between the disease and the socio-economic pressures that lead to deprivation and depression and vice versa.
\end{abstract}

Keywords: diabetes, hipertension, depression, socio-economic deprivation

Diabetes mellitus (DM) and High blood pressure/ Hypertension (HTN), apart of cancer [1], are at increased risk for anxiety, eating disorders and depression which can lead to serious complications, all of them altering quality of life. There are three monoamines known as neurotransmitters, playing an important role in mood regulation:serotonin, norepinephrine and dopamine, apart of others neurotransmitters that function as messengers in the brain, glutamate, GABA, and acetylcholine included [2]. Depression has been linked to imbalances in the brain with regard to these three neurotransmitters. Lower-thannormal levels of neurotransmitters produce symptoms such as:feelings of sadness, helplessness, worthlessness, overeating or loss of appetite, insomnia or sleeping too much, restlessness, irritability, lack of energy, distancing themself from others, feeling numbness or lacking empathy, inability to concentrate, thoughts of hurting themself or others and so on [3]. These symptoms could be screened with Beck Depression Inventory (BDI) which is a valuable substitute for the lack of reliable tests for brain chemical imbalance.

Previous studies have shown that coexistence of mental disorders such as anxiety and depression are considerably more frequent in people with DM and HTN than in the overall population $[4,5]$, with a prevalence ranging from $15 \%$ to $24 \%$ and an incidence rate of depression during the first year after initiation of oral antidiabetic treatment of 12.61 per 1000 person-years [6] and 56\% for HTN [5]. Depression occurrence is two to three times higher in people with DM, the majority of the cases being underdiagnosed, as it is in HTN.

In 2015, the prevalence of diabetes worldwide was of one in 11 adults and the estimated prevalence of the impaired glucose toleration was of one in 15 adults. These numbers are expected to further increase, especially in the urban population, leading to more medical and economic challenges, added on top of the $12 \%$ global health expenditure currently spent on diabetes [7]. A recent study conducted in the Romanian population showed that diabetes is one of the major health care problems for our medical system, as its prevalence is of $11.6 \%$ and the prediabetes one is of $16.5 \%[8,9]$.

Evidences of the involvement of insulin signaling on brain mechanisms related to depression indicate that insulin resistance, a hallmark of Type 2 DM, could develop in the brains of depressive patients [10]. Some clinical reports and meta-analyses indicate a correlation between Type 2DM and depression with a bi-directional increased risk between both conditions [11]. Insulin has been implicated with diverse central roles, like modulating feeding behavior and energy maintenance by the hypothalamus, as well as memory-related processes by the hippocampus [12]. High-fat diet (HFD) impairs cell proliferation, insulin signaling and the Akt/glycogen synthase kinase $3 \beta$ (GSK3 $\beta$ ) activation promoted by serotonin in the dentate gyrus of the hippocampus [13].

Chronic psychological stress is associated with neuropsychiatric diseases, including depression and also with Type 2 DM $[14,15]$. Such a situation occurs with a notable magnitude when socio-economic deprivation elements exist, which can also be measured with EPICES score, a tool for detecting patients at high risk of diabetic complications (and not only) and poor quality of life [16]. Like patients with other chronic medical conditions, HTN patients experience many profound emotions which increase their risk for the development of mental health disorders particularly anxiety and depression [17] and even stroke and death [18]. There are also associations between cardiovascular disease (HTN) [19] and socio-economic deprivation $[20,21]$.

We studied EPICES score in relation with BDI in apparently healthy population, (meaning that there were no knownpsychiatric documented disorders of the subjects) aged 20-90, in order to evaluate, by means of 
receiver operating characteristic (ROC) curves, whether cognitive vulnerabilities (CV) exist, and independently to discriminate between subjects with different severities of depression in relation with socio-economic deprivation [22]. Depression was classified to 0-13: minimal;14-19: mild, 20-28: moderate, 29-63: severe depression. Deprivation cutoff was 30, no deprivation=EPICES score under 30, deprivation=EPICES score over 30.

\section{Hypotheses}

The alternative hypothesis: there ismore risks for chronically ill individuals (i.e. DM and HTN) with socioeconomic deprivation to develop depression. The null hypothesis: all individuals are at the same risks for depression.

\section{Population and main outcome measures}

Sample size: One thousand eighty-one $(1,081)$ subjects responded to both EPICES and BDI questionnaires between January-J une 2019, Confidence Level 95\%, 300,000 total population aged 20-69, percentage 50, for Confidence Interval of 2.3. Socio-demographic data were: age, gender, residence, level of education, occupation, marital status in $\mathrm{BDI}$, chronic illness if present and also items required by EPICES score (an individual index of deprivation, the Evaluation de la Precarite et des Inegalites de santé dans les Centres d'Examens de Sante (Evaluation of Precarity and Inequalities in Health Examination Centers [EPICES]) score computed on the basis ofindividual conditions of deprivation [23] (social worker contacts, private health insurance, home ownership, financial difficulties, practicing sports, attending a spectacle, taking a vacation, having social life, finding a place to stay or a help in need).

\section{Experimental part Methods}

The EPICES score was used as a quantitative or as a dichotomous variable with the EPICES median considered as the cutoff value to divide the population into two subgroups: less deprived with a score $\leq 30$ and more deprived with a score $\geq 30$. Correlations among the EPICES score, subjects characteristics, and BDI scores as variables were calculated by Pearson coefficients. Comparisons of less deprived with more deprived subjects for their sociodemographic characteristics and depression scores as variables, were analyzed by chi-squared tests and $t$ tests as appropriate. Associations were first considered statistically significant at two-tailed 0.05 . Cronbach's Alpha was performed for both BDI and EPICES scores.

\section{Results and discussions}

The socio-demographic and clinical characteristics of the 1,081 responders are reported in table 1 . The mean age was 42.27 (SD 14.666) and $56.8 \%$ were female. The BDI score mean value was 16.31, Standard deviation SD (SD 12.925), with extreme values 0-56.The EPICES score mean value was 50.12 (SD 17.09273) with extreme values 7.10-100.DM was present in $11.47 \%(n=124)$ and HTN in $26.27 \%(n=284)$ of the responders. Depression was prevalent in $40.76 \%(n=505)$ of our sample, which is worrying; chronic illness was prevalent in $37.74 \%(n=408)$ and $64.95 \%$ of them were depressed $(n=265)$ compared to $35.66 \%(n=240)$ of non chronically ill subjects.

The EPICES score was strongly correlated to BDI score (positive correlation, $r 0.578, \mathrm{P}<0.001$ ) and to chronic illness( positive correlation, $r 0.280 ; P<0.000$ ). The result of the simple ANOVA F test $(3.1077)=261.690 ; p<0.001$ is consistent with these results and confirms that there are significant differences between the four classes of depression in terms of EPICES scores, table 2. The average of EPICES scores is significantly higher in those with severe depression compared to all other classes and significantly lower in those with minimal depression than those with mild, moderate and severe depression.

Table 1

BDI AND EPICES SUBJ ECTS CHARACTERISTICS

\begin{tabular}{|c|c|c|c|}
\hline item & category & Number & $\%$ \\
\hline \multirow[t]{2}{*}{ residence } & rural & 529 & 48.94 \\
\hline & urban & 552 & 51.06 \\
\hline \multirow[t]{5}{*}{ maritalstatus } & cohabitation & 188 & 17.39 \\
\hline & divorced & $83^{-}$ & $7.68^{-1}$ \\
\hline & married & 509 & 47.09 \\
\hline & not married & 270 & 24.98 \\
\hline & widower & 31 & 2.87 \\
\hline \multirow[t]{5}{*}{ occupation } & employee & 562 & 51.99 \\
\hline & no occupation & 172 & 15.91 \\
\hline & retired & 156 & 14.43 \\
\hline & student & 73 & 6.75 \\
\hline & unemployed & 118 & 10.92 \\
\hline \multirow[t]{8}{*}{ education } & no education & 28 & 2.59 \\
\hline & 4grade & 14 & $1.30^{--}$ \\
\hline & 8grade & 200 & 18.50 \\
\hline & 10 grade & 10 & 0.93 \\
\hline & 12 grade & 336 & 31.08 \\
\hline & college & 237 & 21.92 \\
\hline & university & $234^{-}$ & 21.65 \\
\hline & postuniversity & 22 & $2.04^{-}$ \\
\hline \multirow[t]{2}{*}{ depression } & $\mathrm{DM}$ & 265 & 24.51 \\
\hline & no DM & 240 & 22.20 \\
\hline \multirow[t]{2}{*}{ no depression } & $\mathrm{DM}$ & 143 & 13.23 \\
\hline & no DM & 433 & 40.06 \\
\hline \multirow[t]{2}{*}{ deprivation } & $\mathrm{DM}$ & 393 & 36.36 \\
\hline & no DM & $564^{-}$ & 52.17 \\
\hline \multirow[t]{2}{*}{ no deprivation } & $\mathrm{DM}$ & 15 & 1.39 \\
\hline & no DM & 393 & -36.36 \\
\hline
\end{tabular}

By comparing chronically ill patients with others, we observed an average of EPICES score significantly higher in chronicallyill patients, $\mathrm{t}(1,079)=9.568 ; \mathrm{p}<0.001$, mean EPICES $=46.40$ versus 56.25 . The mean BDI score is also significantly higher in chronically ill patients, $\mathrm{t}(1,079)=$ 15.276; $p<0.001$, mean $B D I=23.30$ versus 12.07. In terms of gender differences, there is a significant difference between men and women in the Beck Depression score, with men achieving higher mean scores than women $t$ $(1,079)=28.895 ; p<0.001$ (mean $M=18.14$, mean $\mathrm{F}=14.92)$. There were no significant differences between the two groups in the EPICES score.

The psychometric properties of the BDI and EPICES score in the study sample were assessed by Cronbach's Alpha. Internal consistency for BDI shows an excellent Cronbach's Alpha of 0.941; Cronbach's Alpha Based on Standardized Items of 0.944 , for 21 items, table 3 , meaning that depression symptoms were accurate recognized and described by the subjects. 


\begin{tabular}{|c|c|c|c|c|c|c|c|c|}
\hline \multirow[t]{2}{*}{ Depression } & \multirow[t]{2}{*}{$\mathbb{N}$} & \multirow[t]{2}{*}{ Mean } & \multirow[t]{2}{*}{ Std. Deviation } & \multirow[t]{2}{*}{ Std. Error } & \multicolumn{2}{|c|}{$\begin{array}{c}95 \% \text { Confidence Interval for } \\
\text { Mean }\end{array}$} & \multirow[t]{2}{*}{ Minimum } & \multirow[t]{2}{*}{ Maximum } \\
\hline & & & & & Lower Bound & Upper Bound & & \\
\hline minimal & 576 & 39.87 & 12.83770 & 0.53490 & 38.8222 & 40.9234 & 7.10 & 89.94 \\
\hline mild & 92 & 58.04 & 14.96341 & 1.56004 & 54.9418 & 61.1395 & 28.40 & 100.00 \\
\hline moderate & 233 & 60.77 & 13.00233 & 0.85181 & 59.0974 & 62.4540 & 20.11 & 100.00 \\
\hline severe & 180 & 65.08 & 12.53825 & 0.93455 & 63.2430 & 66.9313 & 29.58 & 91.72 \\
\hline Total & 1081 & 50.12 & 17.09273 & 0.51987 & 49.1029 & 51.1430 & 7.10 & 100.00 \\
\hline
\end{tabular}

Table 2

DEPRESSION TYPES AND EPICES SCORES

\begin{tabular}{|l|r|r|r|}
\hline & $\begin{array}{c}\text { Scale Mean if } \\
\text { Item Deleted }\end{array}$ & $\begin{array}{c}\text { Scale Variance if } \\
\text { Item Deleted }\end{array}$ & $\begin{array}{c}\text { Cronbach's Alpha if } \\
\text { Item Deleted }\end{array}$ \\
\hline Sadness & 15.71 & 154.337 & 938 \\
\hline Pessimism & 15.60 & 147.449 & .936 \\
\hline Past failure & 15.50 & 152.261 & .937 \\
\hline Loss pleasure & 15.55 & 153.223 & .937 \\
\hline Guilt feelings & 15.70 & 152.165 & .937 \\
\hline Punishment feel & 15.26 & 151.276 & .942 \\
\hline Self dislike & 15.67 & 151.870 & .937 \\
\hline Self criticalness & 15.44 & 157.235 & .940 \\
\hline Suicidal & 15.81 & 152.813 & .938 \\
\hline Crying & 15.45 & 147.468 & .938 \\
\hline Agitation & 15.25 & 153.470 & .937 \\
\hline Loss interest & 15.50 & 151.506 & .937 \\
\hline Indecisiveness & 15.51 & 151.759 & .935 \\
\hline Worthlessness & 15.53 & 147.160 & .937 \\
\hline Loss energy & 15.62 & 151.427 & .938 \\
\hline Sleep & 15.30 & 149.018 & .937 \\
\hline Irritable & 15.49 & 152.802 & .938 \\
\hline Appetite & 15.68 & 152.681 & .945 \\
\hline Concentration & 15.65 & 162.424 & 938 \\
\hline Tiredness & 15.50 & 152.948 & 150.083 \\
\hline Sex interest & 15.61 & & 938 \\
\hline
\end{tabular}

Table 3

BDI ITEM-TOTAL STATISTICS
Internal consistency for EPICES score shows a modest but acceptable Cronbach's Alpha of 0.526; Cronbach's Alpha Based on Standardized Items of 0.521, for 11 items, table 4.

As an explanation for all AUC values under 0.5 of Cronbach's Alpha for EPICES score we could try to understand the role of cultural and traditional way of life in Romania, where sports is not an adult habit, attending a spectacle has a different meaning from that of Western Europe, taking a vacation is an opportunity for renovation, cleaning, or preparation for winter/autumn reserves and so forth. Finding a shelter when needed might mean spending a few days with relatives and borrowing money from them or from friend and so on, as a patriarchal society is functioning.

The ROC curve was used to determine an appropriate cutoff, affecting the sensitivity and specificity of both BDI and EPICES score in relation with chronic illness. The area under the ROC curve (AUC) is a global measure of the ability of a test to discriminate whether a specific condition is present or not present. An Area Under the Curve (AUC) of 0.5 represents a test with no discriminating ability, while an AUC of 1.0 represents a test with perfect discrimination, Figure 1. For depression in relation with chronic illness AUC was $0.646, P<0.000$ and for deprivation was 0.563 , $\mathrm{P}=0.001$, meaning that both are appropriate tools, in terms of sensitivity and specificity for detecting chronic illnessdeprivation-depression significance in a sample. For EPICES scores in relation to chronic illness AUC is $0.881, P<0.000$. Chronic condition is associated with depression in men, $P=0.0240$ and with deprivation in both gender, $P<0.0001$. Relative Risk for depression in men is RR 1.1627times higher than in women $(95 \% \mathrm{Cl} 1.0243$ to $1.3198, \mathrm{P}=$ $0.0197)$ and chance Odds Ratio (OR) for detecting their depression is1.3303times higher $(95 \% \mathrm{Cl} 1.0449$ to 1.6938 , $\mathrm{P}=0.0206$ ) compared to women.

Relative Risk RR for depression in chronic condition is 2.1137 times higher than in healthy subjects ( $95 \% \mathrm{Cl} 1.7929$ to $2.4918, P<0.000$ ) and chance Odds Ratio (OR) for detecting their depression is 3.3434 times higher $(95 \% \mathrm{Cl}$ 2.5847 to $4.3248, \mathrm{P}<0.000)$. RR for deprivation in chronic condition is 3.3948 times higher than in healthy subjects $(95 \% \mathrm{Cl} 2.0996$ to $5.4890, \mathrm{P}<0.0001)$ and chance OR for detecting their deprivation is 5.0635 times higher $(95 \% \mathrm{Cl}$ 2.9070 to 8.8196, $P<0.0001$ ).

$\mathrm{RR}$ for depression in $\mathrm{DZ}$ is 1.8583 times higher than in healthy subjects $(95 \% \mathrm{Cl} 1.6535$ to $2.0886, \mathrm{P}<0.0001$ ) and OR for detecting their depression is 5.0936 times higher 


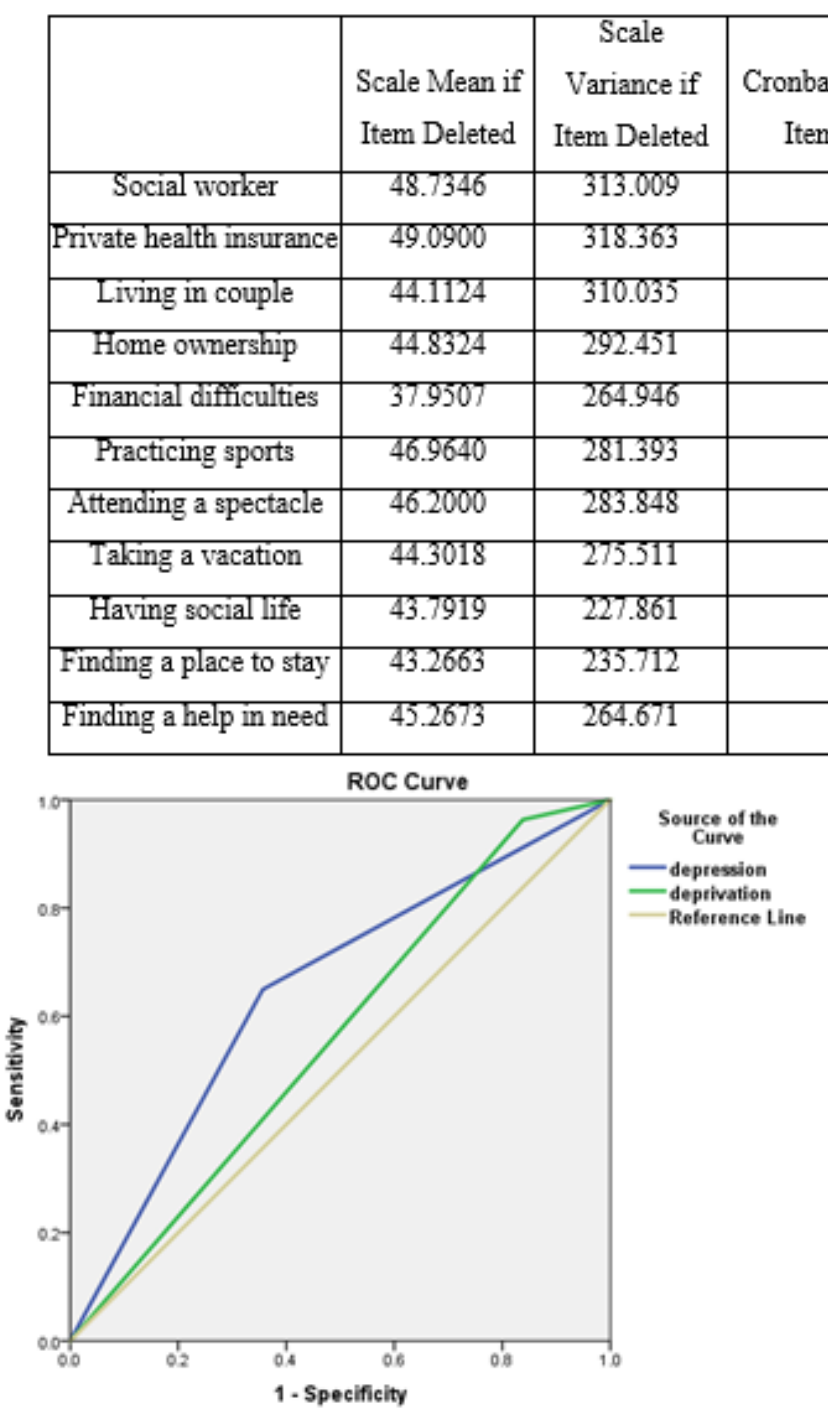

Fig. 1. ROC curve for depression in chronically ill patients depending on depression and deprivation score

(95\% Cl 3.2446 to 7.9961, $\mathrm{P}<0.0001$ ).RR for depression in HTN is 1.3742 times higher than in healthy subjects ( $95 \%$ $\mathrm{Cl} 1.2103$ to $1.5603, \mathrm{P}<0.0001$ ) and OR for detecting their depression is1.9006times higher $(95 \% \mathrm{Cl} 1.4442$ to 2.5013 , $P<0.0001$ ).

RR for deprivation in DM is 1.1448times higher than in healthy subjects $(95 \% \mathrm{Cl} 1.1144$ to $1.1760, \mathrm{P}<0.0001)$ and OR for detecting their deprivation is 37.1932 times higher $(95 \% \mathrm{Cl} 22.2987$ to $601.7976, \mathrm{P}=0.0109)$. RR for deprivation in HTN is slightly increased 1.0579times higher than in healthy subjects $(95 \% \mathrm{Cl} 1.0135$ to $1.1043, \mathrm{P}=$ 0.0101 ) and $O R$ for detecting their deprivation is 1.7478 times higher $(95 \% \mathrm{Cl} 1.0792$ to $2.8307, \mathrm{P}=0.0232)$ (Figure 2).

\section{Conclusions}

DM and deprivation is, no doubt, a twin problem in Arad County. The association between DM and HTN with depression has been well known for at least three decades $[24,25,26,27]$. DM and HTN frequently occur together; there is substantial overlap between diabetes and hypertension in etiology and disease mechanisms because obesity, inflammation, oxidative stress, and insulin resistance are thought to be the common pathways [28-31]. The prevalence of depression in people with DM or HTN varies widely. We analyzed the depression in a cohort of patients with DM and HTN from Arad County based on Beck Depression Inventory as the screening tool in correlation
Table 4

EPICES SCORE ITEM-TOTAL STATISTICS

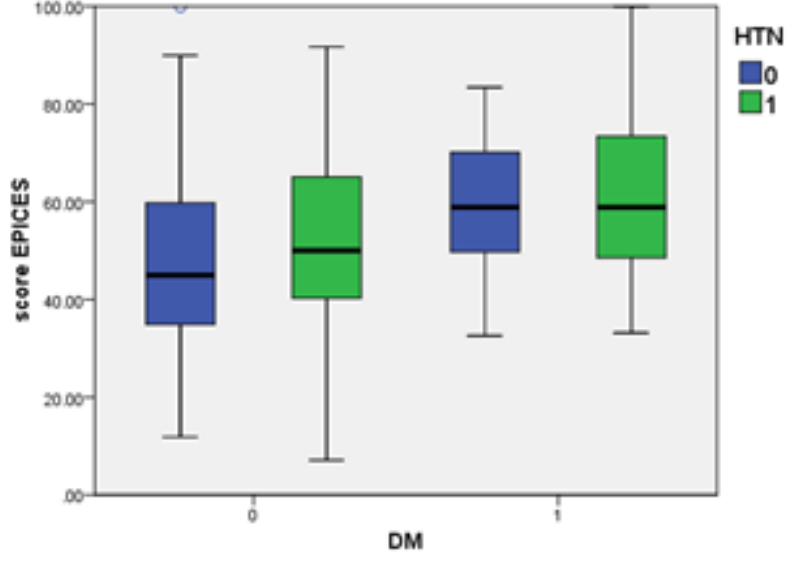

Fig. 2. Diabetes mellitus and Hypertension in relation with EPICES score

with deprivation scores established with EPICES index to measure individual deprivation.

Half of Romania's population (50\%) suffered from material and social deprivation in 2016, this being the highest rate registered in the European Union (EU), according to data from the European statistics office Eurostat [32]. Only Bulgaria had a rate close to that of Romania, namely $48 \%$. Other EU Member States with high rates were Greece (36\%), Hungary (32\%) and Lithuania (29\%) [32].

The improvement of these parameters depends very much on the health policies and the practice of each state [33-41].

The socio-economic deprivation is a powerful predictor of the prevalence and persistence of depressive symptoms.

\section{References}

1.TATARU AL, FURAU G, et al, Journal of clinical medicine, 8, no. 1, 2019, Article Number 96

2.***American Psychiatric Association (2013). Diagnostic and statistical manual of mental disorders, fifth edition. Arlington, VA: American Psychiatric Association.

3.MELENDEZ J C, ALFONSO-BENLLIURE V, MAYORDOMO T, Aging \& Mental Health, 22, no. 12, 2018, p. 1606-1613.

4.KNOL MJ, TWISK JW, BEEKMAN AT, et al., Diabetologia, 49, 2006, p. 837-845.

5.KRETCHY I, OWUSU-DAAKU F and DANQUAH S, Int J Ment Health Syst., 8, 2014, p. 25. 
6.LUNGHI C, MOISAN J, GREGOIRE JP, et al., Medicine, 95, 2016, p. 3514

7.***International Diabetes Federation. IDF Diabetes, 7 ed., 2015, Brussels, Belgium: International Diabetes Federation, http:// www.diabetesatlas.org.

8.MOTA M, POPA SG, et al, PREDATORR study., J Diabetes, 2015. 9.POP A, CLENCIU D, ANGHEL M, RADU S, SOCEA B, MOTA

E, MOTA M, PANDURU NM; ROMDIANESTUDY GROUP, J ournal of Diabetes, 8, no. 2, 2016, p. 220.

10.SHEPERD PR, KAHN BB., N Engl J Med., 341, 1999, p. 248-257.

11.SVENNINGSSON I, BJ ORKELUND C, et al., Scand J Caring Sci., 26, 2012, p. 349-354.

12.GRILLO CA, PIROLI GG, et al., Diabetes, 64, 2015, p. 3927-3936.

13.PAPAZOGLOU IK, JEAN A, et al., Mol Neurobiol., 52, 2015, p. 363374.

14.VISEU J, LEAL R, et al. Psychiatry Res., 268, 2018, p. 102-107.

15.SOCEA B, NICA AA, SMARANDA A, CARAP AC, CONSTANTIN VD. Biomarkers predicting acute necrotizing enterocolitis in decompensated diabetes. Proceedigs of Interdiab 2019, Niculescu Editure, ISSN 2393-3488, p. 350.

16.BIHAN H, RAMENTOL M, et al., Diabetes Metab., 38, no. 1, 2012, p. 82-85.

17.MITRANOVICI, M.I., PUSCASIU, L., et al, Rev.Chim.(Bucharest), 68, no. 12, 2017, p. 2970-2973.

18.UIVAROSAN D, ABDEL-DAIM M., et al, Farmacia, 66, no. 5, 2018, p. 826-830.

19.DEJEAN D, GIACOMINI M, et al., Ont Health Technol Assess Ser., 13, no. 16, 2013, p.1.

20.BORUSZ K, JUHASZ A, et al., Front Pharmacol., 9, 2018, p. 839.

21.POPA, A.R., VESA, C.M., UIVAROSAN, D., JURCA, C.M., ISVORANU, G., SOCEA, B., STANESCU, A.M.A., IANCU, M.A., SCARNECIU, I., ZAHA, D.C., Rev. Chim. (Bucharest), 70, no. 1, 2019, p. 156.

22.BIHAN H, LAURENT S, et al., Diabetes Care, 28, no. 11, 2005, p. 2680-2685.

23.GUEGUEN R, SASS C, the EPICES WorkingGroup, 2005.

24.ANDERSON RJ, FREEDLAND KE, Diabetes Care, 24, 2001, p. 10691078.

25.CLENCIU, D., TENEA COJAN, T.S., DIJ MARESCU, A.L., ENE, C.G. DAVITOIU, D.V., BALEANU, V.D., CIORA, C.A., SOCEA, B., VOICULESCU, D.I., NEDELCUTA, R.M., CALBOREAN, V., GHEORMAN, V., VLADU, I.M., Rev. Chim. (Bucharest), 70, no. 4, 2019, p. 1434.

26.VLADU, I.M., RADU, L., GIRGAVU, S.R., BALEANU, V., CLENCIU, D., ENE, C.G., SOCEA, B., MAZEN, E., CRISTEA, O.M., MOTA, M., TENEA COJAN, T.S., Rev. Chim. (Bucharest), 69, no. 11, 2018, p. 4229.
27.SOCEA, B., RADU, L., CLENCIU, D., TENEA COJAN, T.S., BALEANU, V., ENE, C.G., GIRGAVU, S.R., VLADU, I.M., Rev. Chim. (Bucharest), 69, no. 11, 2018, p. 4012

28.BERNARD MY and CHAO L,, Curr Atheroscler Rep., 14, no. 2, 2012, p. 160-166.

29.SOCEA, L.I., SARAMET, G., SOCEA, B., DRAGHICl, C., Rev. Chim. (Bucharest), 57, no. 12, 2006, p. 1242.

30.MANEA, M., MARCU, D., STOIAN, A.P., GAMAN, M.A., GAMAN, A.M., SOCEA, B., NEAGU, T.P., STANESCU, A.M.A., BRATU, O.G., DIACONU, C.C., Rev. Chim. (Bucharest), 69, no. 11, 2018, p. 4180.

31.GHEORGHE, G., PANTEA STOIAN, A., GAMAN, M.A., SOCEA, B., NEAGU, T.P., STANESCU, A.M.A., BRATU, O.G., MISCHIANU, D.L.D., SUCEVEANU, A.I., DIACONU, C.C., Rev. Chim. (Bucharest), 70, no. 2, 2019, p. 651.

32.***https://ec.europa.eu/eurostat/statisticsexplained/index.php? title $=$ Income poverty statistics

33.DIMITRIU, M., SOCEA, B., IONESCU, C.A., PLES, L., GHEORGHIU. D.C., CONSTANTIN, V.D., CIRSTOVEANU, C.G., BACALBASA, N., FURAU, C.G., DAVITOIU, D.V., GHEORGHIU, N., Rev. Chim. (Bucharest), 70, no. 4, 2019. p. 1248-1250.

34.DIMITRIU, M., SOCEA, B., PLES, L., GHEORGHIU, D.C., GHEORGHIU, N., NEACSU, A., CIRSTOVEANU, C.G., BACALBASA, N., FURAU, C.G., FURAU, G.O., BANACU, M., IONESCU, C.A., Rev. Chim. (Bucharest), 70, no. 3, 2019, p. 1058-1061.

35.DIMITRIU, M.C.T., IONESCU, C.A., GHEORGHIU, D.C., SOCEA, L.I., BRATU, O.G., CONSTANTIN, V.D., PLES, L., NEACSU, A., BOBIC, S., SOCEA, B., Rev. Chim. (Bucharest), 69, no. 9, 2018, p. 2391-2395.

36.NEACSU, A., CALIN, A., BRAILA, A.D., NAVOLAN, D., DIMITRIU, M., STANICA, C.D., IOAN, R., IONESCU, C., Rev. Chim. (Bucharest), 69, no. 7, 2018, p. 1796-1801.

37.SOCEA, B., SOCEA, L.I., BRATU, O.G., MASTALIER, B., DIMITRIU, M., CARAP, A., CONSTANTIN, V.D., Mat.Plast., 55, no. 1, 2018, p. 79-81. 38.SOCEA, B., CARAP, A., BRATU, O.G., DIACONU, C.C., DIMITRIU, M., SOCEA, L.I., BOBIC, S., CONSTANTIN, V.D., Mat.Plast., 55, no. 2, 2018, p. 146.

39.IONESCU, A.C., POPESCU, I., BANACU, M., MATEI, A., BOHILTEA, R., DIMITRIU, M., - 5TH ROMANIAN CONGRESS OF THE ROMANIAN SOCIETY OF ULTRASOUND IN OBSTETRICS AND GYNECOLOGY, 2017, p. 194-198.

40.ORBAN H, STAN G, GHEORGHIU N, et al, Chirurgia (Bucharest), 107, no. 2, 2012, p. 226-230.

41.ORBAN HB, GHORGHIU N, CRISTESCU V, Chirurgia (Bucharest), 105, no. 3, 2010, p. 365-372.

$\overline{\text { Manuscript received: } 22.01 .2019}$ 